\title{
Rohingya Massive Exodus into Cox’s Bazar Grows Security Concern: Impacts over Tourism Industry of Bangladesh
}

\author{
Muhammad Tanbirul Islam \\ Research Intern of Bangladesh Institute of Peace and Security Studies (BIPSS), Dhaka, Bangladesh. \\ Email:tanbirul.bcdps@gmail.com Tel: +8801824668548
}

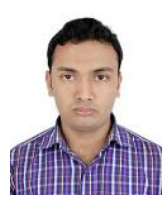

\begin{abstract}
Cox's Bazar, the largest sea beach of the world has reached peak regarding national revenue generation as well as employment creation for Bangladesh, expecting to be a new economic hub. In 2019 it has contributed $4.4 \%$ of national GDP. Therefore, the recent development of Rohingya mass exodus into Cox's Bazar and the increasing number of crimes have become a matter of grave concern to tourists, businessman as well as other associated stakeholders of this sector. The article mainly attempted to figure out different forms of traditional and nontraditional security threat to Cox's Bazar due to Rohingyas. It has found some traditional security threat created by Rohingyas including murder, rape, gang activities, robbery, hijack, abduction, human trafficking, drug trafficking and etc. The article also found some spot crime on beach like stealing, snatching and sweeping the accessories and luggage of tourist by Rohingya youth. It has also given special focus on non-traditional security threat caused by Rohingyas including environmental disaster, and health risks of local community. It figured out the massive settlement of Rohingyas at green and hilly land space that resultantly cleared a large forest area. Some diseases such as Diphtheria, Diarrhea, AIDS have been already broken out as the heath management collapses due to overpressure of Rohingya cases. Tourist arrivals consequently have been declining at alarming rate in Cox's Bazar than last year in 2018. The revenue of tourism industry has also been diminishing that indicates the decline of its contribution to national GDP.
\end{abstract}

Keywords: Rohingya exodus, Security, Environmental cost, Tourism, Economy, Criminal Psychology, Relative deprivation. JEL Classification: Z38 tourism: policy.

Citation | Muhammad Tanbirul Islam (2020). Rohingya Massive Exodus into Cox's Bazar Grows Security Concern: Impacts over Tourism Industry of Bangladesh. Asian Journal of Social Sciences and Management Studies, 7 (3): 236-249.

History:

Received: 15 May 2020

Revised: 22 June 2020

Accepted: 24 July 2020

Published: 20 August 2020

Licensed: This work is licensed under a Creative Commons

Attribution 3.0 License $(\boldsymbol{c c}) \mathbf{E Y}$

Publisher: Asian Online Journal Publishing Group
Funding: This study received no specific financial support.

Competing Interests: The author declares that there are no conflicts of interests regarding the publication of this paper.

Transparency: The author confirms that the manuscript is an honest, accurate, and transparent account of the study was reported; that no vital features of the study have been omitted; and that any discrepancies from the study as planned have been explained.

Ethical: This study follows all ethical practices during writing.

\section{Contents}

1. Introduction

2. Rohingya Refugees

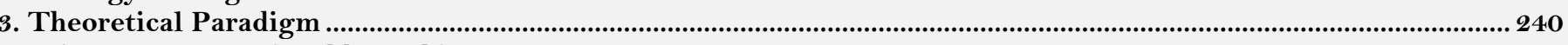

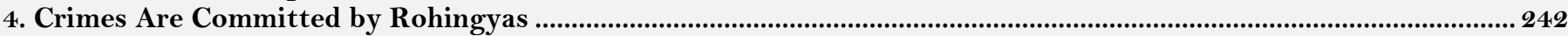

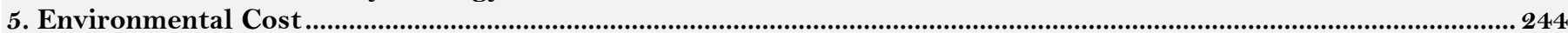

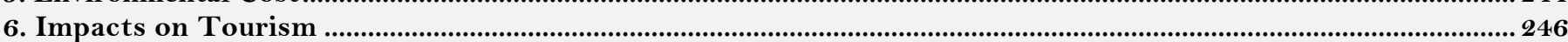

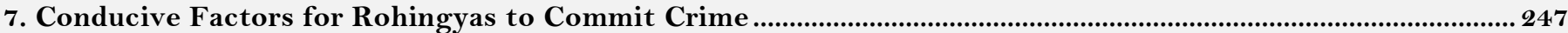

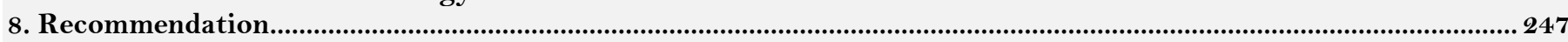

9. Conclusion

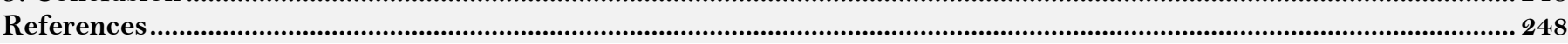




\section{Contribution of this paper to the literature}

This article figured out how the migrants mainly having psychological, social and economic fragility are provoked to engage in crime activities. How and why they are getting motivated to create traditional and non-traditional threats to zonal, national and regional peace.

\section{Introduction}

Rohingya is one of the most persecuted ethnic minorities of the world in UN terms (OHCHR, 2017) have now been residing in Arakan (e.g now Rakhain) for centuries. It has been denied citizenship by for a long time. The military launched its operation Dragon King to clean the nation Myanmar from foreigners in 1977 (Constantine, 2019). Since then the Rohingyas have been forced to leave their homeland, Rakhain, for Bangladesh and continues until present. Recently the crisis has been escalated with a terrorist attack on police and military base by a militant organization named Arakan Roingya Salvation Army (ARSA). In response to such an attack the Myanmar military has launched its large-scale military offensive (Edroos, 2017). The recent military campaign has been accused of committing genocide on Rohingyas by many national and international human rights organizations. Human Rights Watch claimed to have evidence of mass killing, arson attack, gang rape, enforced disappearance and various physical and psychological tortures over the civilians by Military force (Human Rights Watch, 2019). UN has termed the move of Myanmar government as the textbook example of ethnic cleansing (Bruce, 2017). Rohingyas subsequently have started moving into Cox's Bazar and settled down in Teknaf and Ukhiya, two sub district areas of Cox's Bazar (UNHCR, 2019). However, such a large population of Rohingya is now becoming the reason of many problems in Cox's Bazar area. According to law enforcement agencies, the allegations and litigations against the crimes of Rohingyas have been increasing day by day alarmingly (Khan, 2019). The allegation includes murder, rape, narcotics, abduction, human trafficking as well as dacoit. However, it has been apparent in recent days that the security of Cox's Bazar is being threatened day by day. Rohigyas have settled down at hilly forest area, leading it into barren. According to UNDP (2018) thousand acres of forest area have been already cleared as a result of Rohingyas inhabitation. Landslide and soil erosion subsequently have been frequenting in hilly area. The most concerning aspect is about tourism area. The striking natural beauty has been spoiling and the places of tourist spots are also being undersized due to Rohingysa. The environmental cost has been dragging vast consequence for the whole nation. According to the report of WHO in 2019, because of having limited health management facilities compared to large population, several epidemic diseases like diphtheria, dengue, diarrhea and several other communicable diseases have been increasing unchecked (WHO, 2019). As a result, the epidemic has grown concerns among locals and tourists of possible outbreak. Recently Rohingyas are seen in different tourist spots of Cox's Bazar such as Inani beach, Himchori where they have made tents, declining the tourist space along with spoiling the scenic beauty of spots (Patwary, 2017). Besides Rohingyas are also involved at stealing, hijacking, snatching, sweeping the accessories of luggage and suitcases of tourists, those have created an atmosphere of fear among tourists. According to WTTC and World Data Atlas, the number of real tourists has been declined in recent days (WTTC, 2019); (World Data Atlas, 2019). However, the arrivals although are shown sharp increase, but most of them are here for working with NGOs and for other international organizations as local people said. Therefore, this decline has grown a huge concern among the businessman, hotel owners, tourism authority, law enforce agencies and local community who are living on the income from tourism. Tourism is the most potential economic sector of our country. So it is undeniable that the crisis in tourism will produce immeasurable consequences over the national economy (Husain \& Ovi, 2017). Analyst precautions the imaginative geography built upon the good will of Bangladesh' could be hampered by the Rohingya situation (Khan, 2018). This article mainly explored the problematic situation of Cox's bazaar particularly the tourism which is badly affected by Rohingyas. It also focused on increasing number of different nontraditional security threats including militancy, environment damages, health effects, and economic cost. This article is mainly constituted with seven parts. The first part deals with introductory discussion of Rohingyas and their recent move into Bangladesh. The second part contains a theoretical framework, which was designed to demonstrate the critical situation in Cox's Bazar due to Rohingyas. Rohingyas crime activities are talked in third section of this article. The fourth section deals with environmental damages along with health effects due to Rohingya crisis. Some factors are responsible for turning the problem more acute and unchecked which were clearly demonstrated in the sixth part of this article. At the end part of this article, a concluding observation is added along with some probable recommendations to manage the ongoing situation.

\section{Rohingya Refugees}

A Muslim ethnic minority of Rakhain State, who has been residing there for centuries, is still denied citizenship since the military takeover of power in 1962 (Dewan, 2017). However they were officially declined to citizenship in 1982 while the military regime introduced a new law named Burma Citizenship Law 1982. There are 3.6 million Rohingyas populations still in Myanmar among 52 million across the world (Khaliq, 2019). This community has been facing brutal military crackdown by Myanmar military force as well as Buddhist extremists in Rakhain. They were forced to flee from their homeland since the beginning of military crackdown in 1982. The number of their exodus has been reached to 1.1 million until 2018 in according to government (Pennington, 2018).

\subsection{Historical Background of Rohingya Exodus}

Muslim people started settling down at Arakan (e.g. now called Rakhain) since 1430. This state remained independent until the Burmese conquered in 1784. British as a colonial power of Indian subcontinent occupied Arakan in 1824. In 1948, the Burma including Arakan got independence from colonial rule of Britain. From demographic view, it was largely the Buddhist majority area, which has a small number of Muslims alongside other communities like, Hindus and Christians. From very historical age, the Muslims of this area have strong connectivity with the Muslims of neighboring Cox's Bazar area. They are mainly bonded with familial, lingual, and 
ethnic bondages. Therefore, several other ingredients such employment, trade and commerce have played also predominant role in intensifying their mutual proximity with each other. They used to travel each other usually before demarcating the boundary of Pakistan and Myanmar in 1947. It is true that many people from Chittagong had established their inhabitants in Arakan, as people from Arakan settled down in Cox's Bazar. Britain, then colonial power, promised to offer autonomy status to Arakan Muslim, which was not fulfilled even after the independence of Myanmar from colonial rule. The ethnic identity of Rohingya Muslim was not even also recognized by the Myanmar government (Albert \& Maizland, 2020).

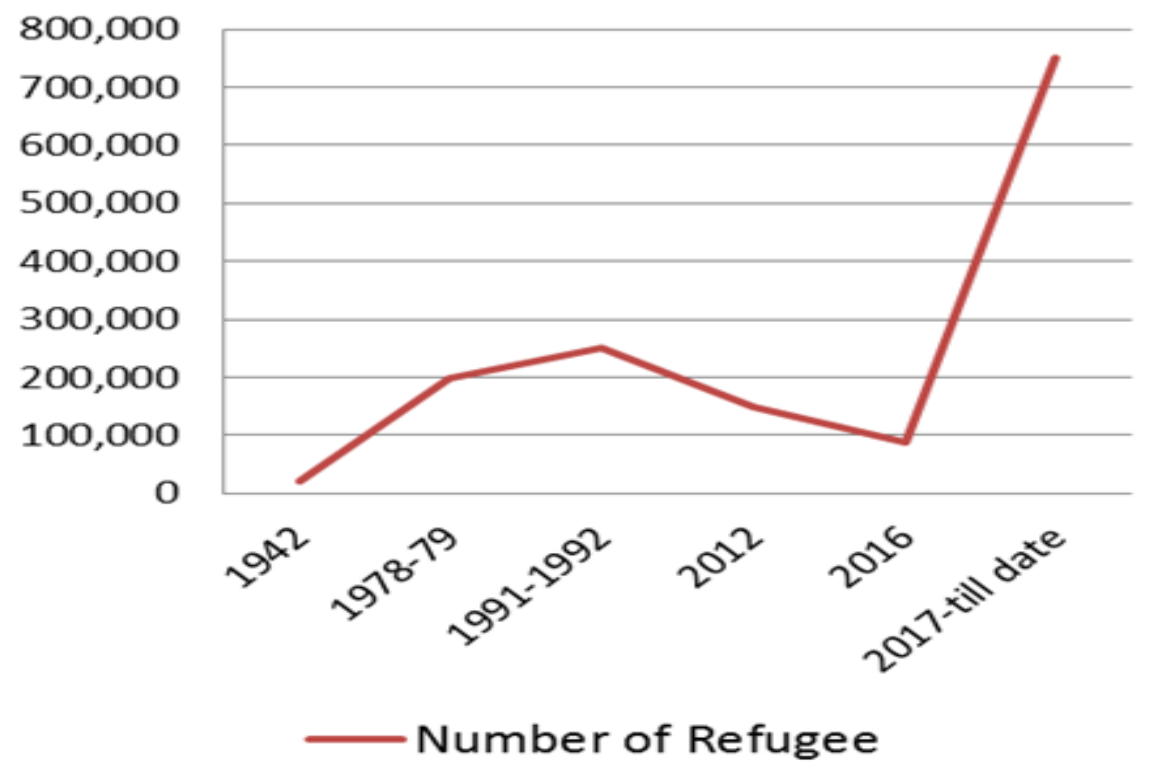

Figure -1. The growing number of rohingyas in Bangladesh Source: Prepared by author based on Human Rights Watch (2019); Khaliq (2019).

\section{Ratio of Local and Rohigyas}

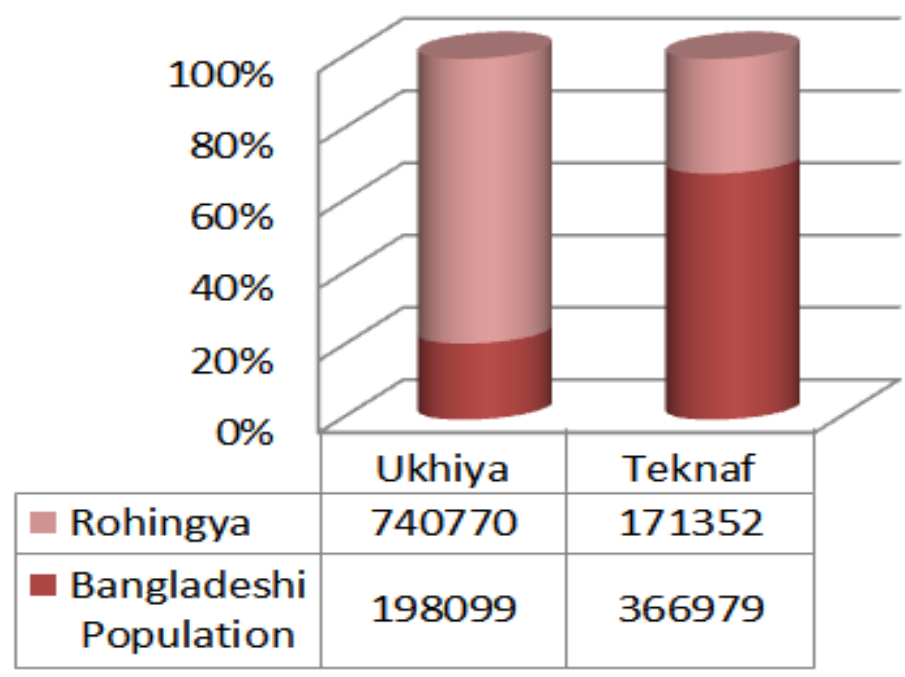

Figure-2. Ratio of local people and Rohingyas in Ukhiya and Teknaf Source: Prepared by author based on; UNDP Bangladesh (2018).

The junta regime came into rule of Myanmar in 1962 and started military offensive against so called foreigners. The forceful migration started from then. The Junta regime introduced a new citizenship law in 1982. The law defined the criteria of getting citizenship particularly for the unrecognized ethnic minorities of Myanmar. It officially denied giving citizenship status to Rohingyas which refueled the tension in that region. The military instantly began offensive campaign against Muslim minorities that has been undergoing until present with having some intervals (Arraiza \& Vonk, 2017). In 1977 Myanmar junta regime started its first military campaign named "Operation Dragon King". It was mainly for excluding the foreigners from Myanmar. It took a program to register its own citizen. Thus the Roingya whole community was alienated from the rest of the population and subsequently was subjected to torture by military as they were termed as the foreigners. As a result a large number of Rohingyas were forced to mobilize into Bangladesh. It was estimated nearly 200,000 Rohingyas had migrated to Bangladesh during 1977-78. Therefore a repatriation treaty between Bangladesh and Myanmar had been signed in 1978 and around 180,000 Rohingyas were allowed to go back into Myanmar. For the first time in 1982, Myanmar officially declared the list of its ethnic communities. In that declaration Rohingya was denied as an ethnic community though Myanmar, the then military government officially recognized 135 ethnic communities. In 1990, nearly 200,000 Rohingyas again moved into Bangladesh from their homeland in face of military crackdown. With the collaboration of UNHCR, a repatriation deal had been signed in 1992 and again Bangladesh could repatriate around 230,000 Rohingyas into Myanmar. In 2012 Rohingyas faced another brutal military crackdown. Subsequently a large number of Rohingyas, nearly 150,000, came into Bangladesh (Human Rights Watch, 2019; Khaliq, 2019). That exodus has been continuing till date although having some intervals. Last in 2017 the influx has been massive. The number of newly migrated Rohingyas has already been reached to 750,000. Bangladesh has now become the host of 
majority Rohingya refugees across the world. Bangladesh officially estimated the number is around 1.1 million in 2019. Therefore the number of Rohingya refugee has been growing alarmingly. It has even now become larger than the local community of those areas (UNDP, 2018).

\subsection{Geographic Location: Rohingya Refugee Camps in Bangladesh}

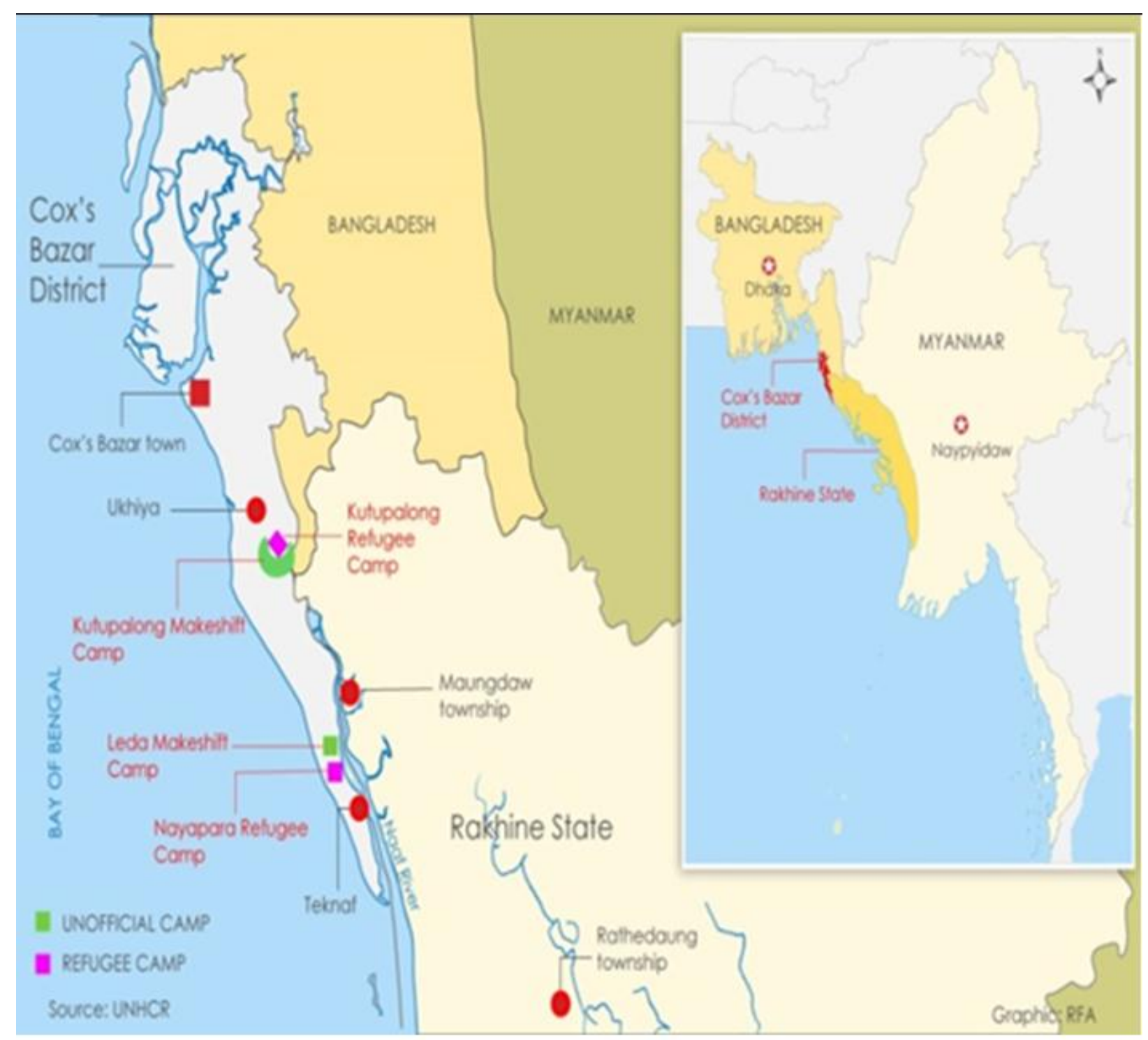

Figure-3. Geographical location of Rohingya refugee camps in Cox's Bazar.

Source: Benar News (2019) based on data of UNHCR.

Rohingyas have settled down mainly in Ukhiya and Teknaf, two sub district areas of Cox's Bazar. Rohingyas are mostly staying at refugee camp. However, though it is restricted but a large number of Rohingyas get mixed into the local community (Illius, 2017). The refugee camps are mainly located at different points of Teknaf and Ukhiya including Hakimpara, Kutapalang, Bagbona, Kunarpara, Moiner Ghona and Thangkhali. The law enforcement agencies including police, BGB and Military force encircled the whole area in order to halt the movement of Rohingyas from campsites to local area. Government is mostly concerned about the infiltration of refugees into city area and particularly tourist areas. However despite the lockdown, Rohingyas recently are seen at many areas of Cox's Bazar city and tourist spots including Inani beach, Himchori and fishari-ghat. Some of them also make tents on beach, roadsides and many other places (Patwary, 2017). Rohingyas due to having common appearances and lingual features with local people cannot be detected easily. The authority recently has revealed that a large number of Rohingyas are gone missing from the campsite (Illius, 2017).

\subsection{Jobs are done by Rohingyas in Tourist Spots}

Rohingyas usually adopt different tricks and ways to earn money on beach. They usually do photography, sale of flowers, gurgle, street peddling, and begging. Rohingya youngsters aged 15-30 mainly do photography on beach at a minimum cost, per photo 20 TK (BDT). Some children sale flowers usually rose and gardenia. Sometimes they bring homemade string and chain with the flowers. They normally attract the travellers and convince them to buy flowers by pleading or requesting. The price of these flowers and ornaments of flowers are from 20- 150 TK (BDT) cost. The young men of Rohingyas act as the porter on the bus station, rail station and before the hotel. They usually carry the luggage, bags and baggage and other different heavy accessories of tourists. They also assist the travellers by doing their heavy works. They offer these works at minimum cost ranged within 50-300 TK (BDT). In somewhere Rohingyas are seen to peddle different accessories and cosmetics products. It carries caracole and necklace for selling. They provide this at 50-200 TK (BDT) cost. Some Rohingyas also serve simple fast food items and water at 30-100 TK (BDT) cost. The sale of coconut at tourist spots is also very demanding that cost (35-50) TK (BDT) per piece. Sometimes in different locations Rohingyas are seen begging. This act is banned by Police but Rohingyas are likely to continue unrestraint. 


\section{Following Myanmar's fleeing Rohingya \\ Since the late 1970 s, nearly one million Rohingya have fled Myanmar due to widespread persecution.}

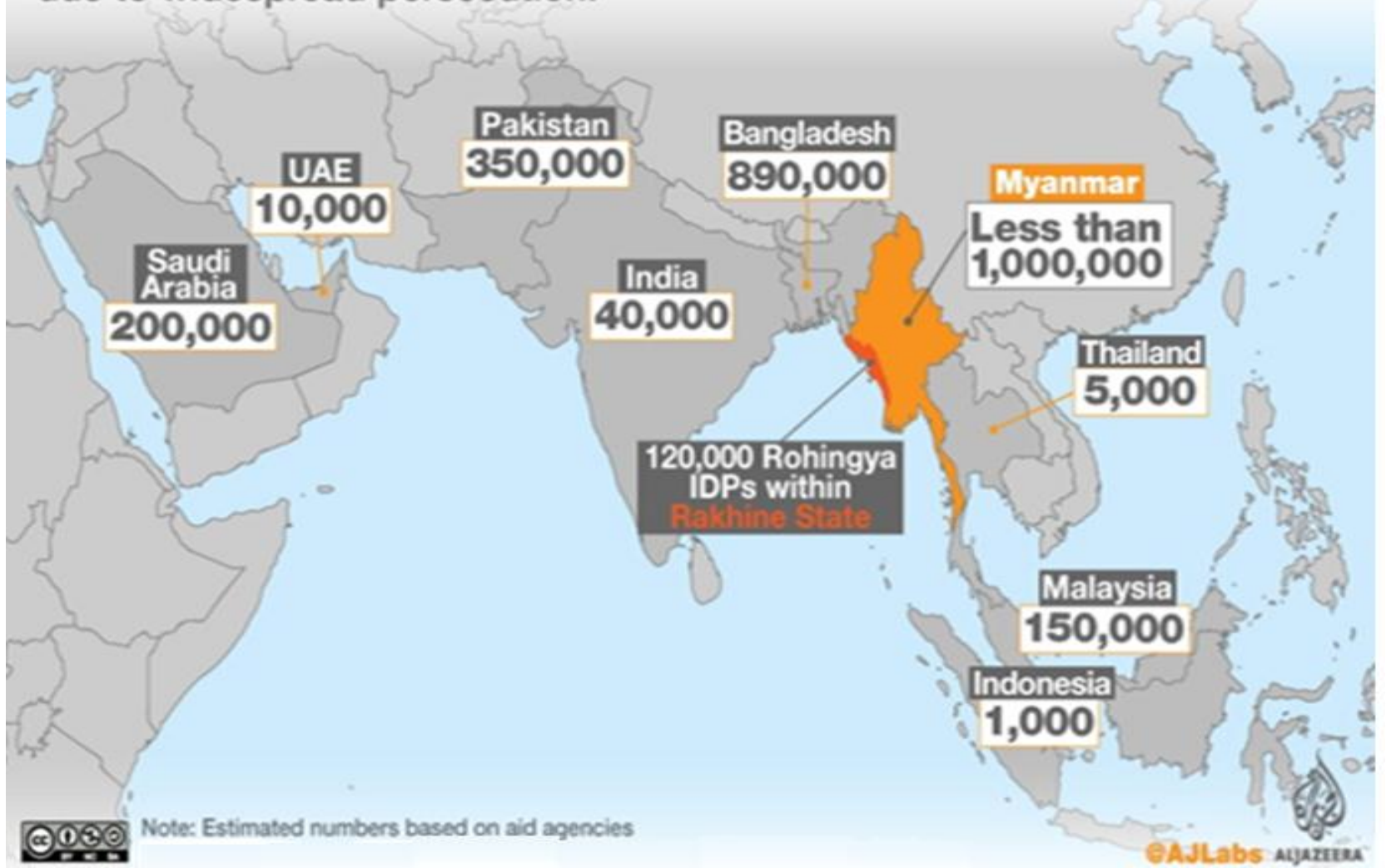

Figure-4. Geographical distribution of Rohingya refugees across the world.

Source: Al-Jazeera News (2018) based on UNHCR and IOM.

\section{Theoretical Paradigm}

The author analyzes the problems caused by Rohingyas in Cox's Bazar through various paradigms and discourses. It mainly focuses on why Rohingyas are prone to committing crime and what factors motivate them to such threatening activities on Cox's Bazar security situation.

\subsection{Relative Deprivation Theory}

The initial concept of Relative Deprivation is simply a psychological aspect. According to Walker \& Pettigrew, Relative deprivation refers to a person who feels deprived of some desirable things relative to their own past, other persons' belongings, eminence and social positions (Walter \& Pettigrew, 1984). Relative deprivation is also perceived as the discrepancy between individual's subjective value expectations and value capabilities. Value expectation means goods and conditions of life that an individual think as their entitlement. Therefore the value capabilities mean to have the ability to achieve their desired goods and conditions of life (Gurr, 1970). Therefore Davis \& Runciman termed it as the eventual outcome of relative comparison on the basis of social categories (Davis, 1959). Runciman explained it from more specific view. He termed this as the comparison among friends, relatives and others closest one. Therefore he analyzed this theory from two grounds. One is egoistical that is individual centric and other is fraternal that is group centric (Runciman, 1966). Crosby set a model through mentioning five preconditions that defined the individual extent of relative deprivation in Figure 5 (Crosby, 1976).

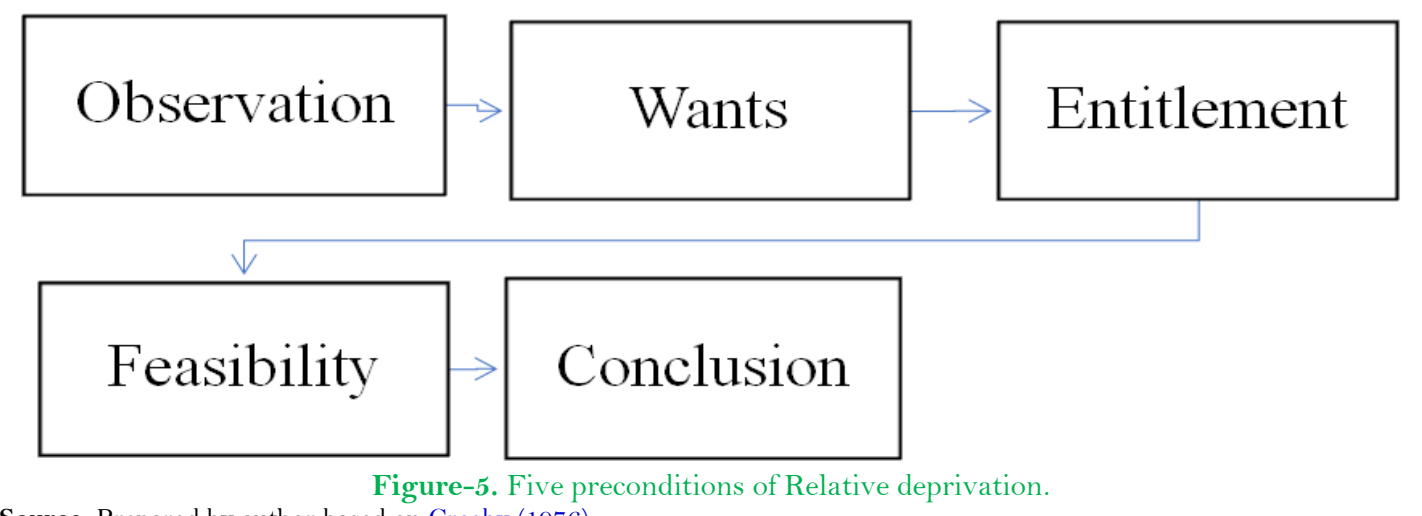

Source: Prepared by author based on Crosby (1976)

1) A person observes other person who possesses the desirable goods and conditions of life.

2) He desires to get that goods and conditions what he observed.

3) He feels entitled to get such desirable goods and conditions in his own life.

4) He started to think, that things is feasible to attain for him.

5) He started blaming the society and system for not possessing these desirable goods and conditions of life Crosby also denoted two eventual outcomes if the desirable goods and conditions of life cannot be met. The one outcome is constructive change in society as positive, and the second one is violence against society as the negative consequence (Crosby, 1976). 


\subsection{Constructive Change in Society}

The desire of an individual most possibly provokes the people to attain that. Then the question of opportunity will arise. If the opportunity is kept open for them, the positive outcome will come through heroic effort from such individual. It is expected that the social leaders, volunteers and other different actors will come forward to assist those people with a view to achieving progress. The changes are also expected to occur in the society through designing an inclusive and constructive strategy. Therefore if desired responses are failed to achieve and goals are not attained, the responsibility will go to the system not over the society. In this, Individual will not go to do violence rather will be inspired to make a positive change in the whole system of the society.

\subsection{Violence against the Society}

It has been common for emigrants, and refugees who are likely denied to get civil, economic, political and even basic rights. The scope, opportunity and platform for achieving desirable goods and conditions of life always not remain unfolded to them. It invokes the refugee to inflict violence in the society. Rohingyas are the most persecuted ethnic minorities of the world as UN termed (OHCHR, 2017). The Relative Deprivation Theory has been perfectly applicable to them. The Rhohingyas have been forced to flee from their home land, in face of Military offensive. They carry the tragic memory of horrific persecution like mass murder, gang rape, burning down the homeland, not having even a minimum level of civil, political and human rights. So the anger and vengeance of them to existing systems have grounded the possibility of inflicting violence in society. At the same time the tourists mainly come from different parts of the world in order to entertain their life. But the luxury of tourist's life may grow a feeling of relative discrimination among Rohingyas as they are not having basic rights guaranteed. So the theory of relative deprivation suggests having sufficient factors on the ground that may provoke Rohingyas to act against society.

\subsection{Theories of Criminal Behavior}

Theories of criminal behavior suggest traumatic experience and stressful environment that are highly responsible for breeding anger and irritability to a victim. It badly impacts traumatized victims and raises the risk of committing antisocial conduct (Elbogen et al., 2012). Post-Traumatic Stress Order is another major element provoke individual to crime attitude. It refers to a psychological torment situation that a traumatized people suffer after trauma incident. It disturbs the victims with frequent flashbacks, nightmares and severe anxiety along with uncontrollable imagination about the incidents. Return to normal life is always hampered by these flashbacks, nightmares and anxiety. They even cannot adjust with their family, friends and the society as well. They feel always scared about life. It contributes to feel them always instable and insecure. Psychologist precautions regarding these people are at risk of getting involved with abnormal activities and horrendous crimes. They are vulnerable of being abused by different local and global actors in order to pursue their political objectives. The different theories of criminal behavior demonstrate how the traumatic experience and stressful environment are highly responsible for leading abnormalities into a victim. Rohingyas are at high risk of being infected by the Posttraumatic Stress Disorder (PTSD) or Traumatic Brain Injury (TBI). Psychologist precautions regarding Rohingyas who are mostly traumatized victims and vulnerable for inflicting an y sort of crimes including brutal offense or militancy activities. In order to demonstrate the fresh impacts of trauma over victim, it is relevant to drag the example of Syrian Refugees in Germany. A study found 32.5\% crimes are committed by the foreigners mostly who came from Syria as refugee while German local populations are responsible for $13 \%$ crimes (The Local, 2017).

\subsection{Freud's Personality Theory}

Sigmund Freud coined a theory named personality theory demonstrated three stages of personality (Sigmund, 1962). The first stage is Id, the second is Ego and the last stage is Super Ego. ID denotes the actual intention of an individual. It is the first stage of building personality. Then the individual get accessed into reality. This is, the second stage, termed as Ego. In the last stage conscience, norms, ethics and values influence and shape the individual acts and behaviors. This third stage is named as Super Ego. First stage ID and the second stage Ego are merged and corrected in this last stage (McLeod, 2019). Rohingya community due to lack of effective parenting and unfavorable social and familial environment, faces high deficit of super ego. They came from a family where norms and values had not been performed properly. The second stage, 'Ego', has been always predominant in their behavior. So it indicates the increase of risks to be more wild and aggressive of them.

\subsection{Maslow's Hierarchy of Needs}

Maslow formulated a theory named 'Hierarchy of Needs' is consisted with five tiers in Figure 6 (Maslow, 1943). Those tiers are shaped as Pyramid. The first two tiers from bottom demonstrate basic needs. It holds physiological needs and safety needs. Human physiological needs include food, water, warmth and rest. Safety needs include security and safety. The second stage is consisted with the need of esteem, belongingness and love refer to the psychological needs. It includes human interactions, relationships and different communication approaches. Then it comes about the last stage termed as self-fulfillment needs. In this stage it holds Self-actualization that is placed at the highest stages of human needs (McLeod, 2019). Rohingyas are actually the victim of basic needs like the deficiency of food, water, warmth, rest, safety and security. These deficiencies badly impact other needs. 


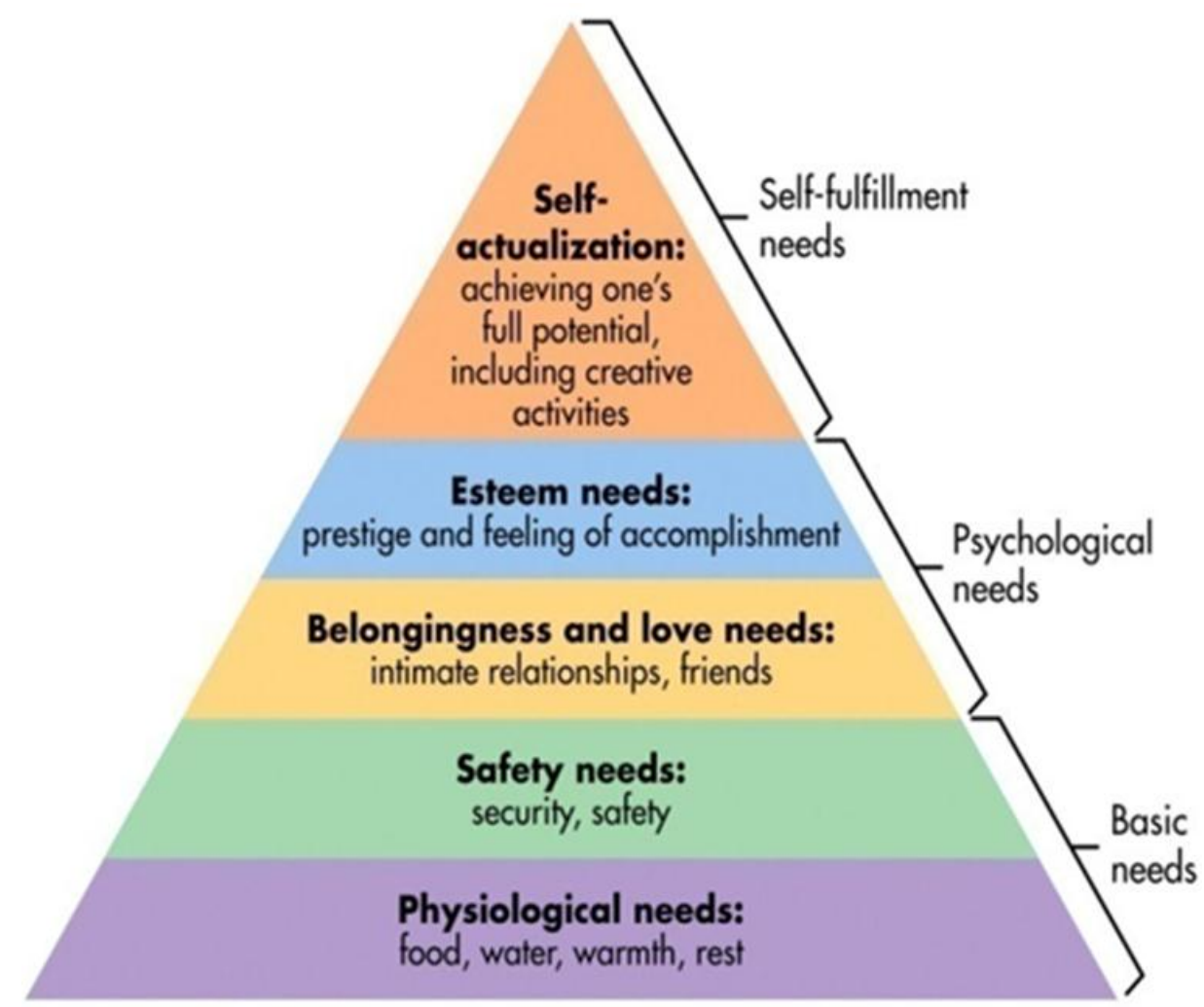

Source: McLeod. (2020)

Figure-6. Pyramid of moslows' hierarchy of needs.

Thus the esteem and gratitude towards local communities of Cox's Bazar in exchange of their considerable sacrifices have been consequently missing to Rohingyas. Rohingyas are seemed mostly desperate in their acts and behavior. This situation actually pushes them to be more prone towards crimes even the heinous crime against the local community without hesitation.

\section{Crimes Are Committed by Rohingyas}

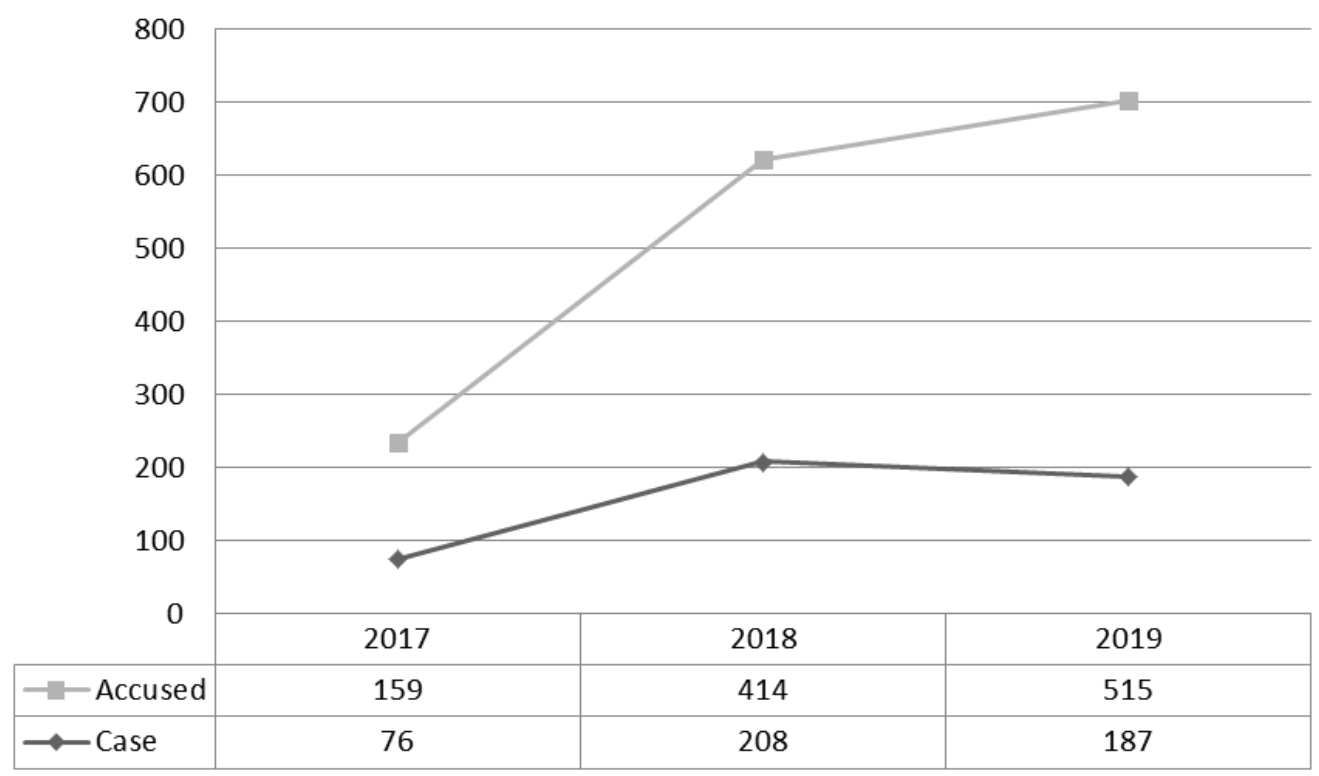

Source: Khan (2019).

Figure-7. The Number of cases against Rohingyas.

Table-1. The Types of Cases against Rohingyas.

\begin{tabular}{l|c|c|c|c|c|c}
\hline \multirow{2}{*}{ Types of Allegation } & \multicolumn{2}{c|}{$\mathbf{2 0 1 7}$} & \multicolumn{2}{c|}{$\mathbf{2 0 1 8}$} & \multicolumn{2}{c}{$\mathbf{2 0 1 9}$} \\
\cline { 2 - 8 } & Cases & Accused & Cases & Accused & Cases & Accused \\
\hline Arms & 12 & 23 & 13 & 21 & 11 & 38 \\
\hline Murder & 8 & 22 & 15 & 33 & 20 & 81 \\
\hline Rape/ attempt to Rape & 2 & 2 & 16 & 27 & 13 & 27 \\
\hline Narcotics & 22 & 40 & 95 & 159 & 91 & 169 \\
\hline Abduction & 0 & 0 & 9 & 39 & 6 & 40 \\
\hline Human trafficking & 0 & 0 & 2 & 8 & 22 & 94 \\
\hline Police assault & 1 & 8 & 0 & 0 & 0 & 0 \\
\hline Dacoity/ attempt to dacoity & 2 & 6 & 7 & 26 & 0 & 0 \\
\hline Filed under the Foreigners Act & 23 & 39 & 12 & 20 & 2 & 13 \\
\hline Filed under the Special Power Act & 2 & 3 & 9 & 20 & 10 & 20 \\
\hline Other crimes & 4 & 16 & 30 & 61 & 12 & 33 \\
\hline Total & 76 & 159 & 208 & 414 & 187 & 515 \\
\hline Source Khn (2019)
\end{tabular}

Source: Khan (2019). 
The Figure 7 reveals the flourishing rate of crime by Rohingyas from 2017, the initial year of recent influx. The number of case against Rohingyas has been sharply increased and it became more than twice within just two years from 2017 to 2019. The Table 1 shows number of accused Rohingyas simultaneously is also increased more than thrice within two years between 2017-2019.

\subsection{Arms}

Recently the news about 6000 sharp objects that were retrieved from a blacksmith shop. Locals alleged those were supposed to distribute among Rohingyas. Some Rohingyas were also arrested for carrying fire arms, as news reported. A senior politician Tofail Ahmed cited it as he said, "We now see a deep-rooted conspiracy going on" (Bdnews24.com, 2019). In Cox's Bazar 144 local and international NGOs set up their office according to Bangladesh NGO Bureau affairs (Mahmud, 2018). Some NGOs are suspended for being alleged to provide arms among Rohingya youths. Foreign ministry termed these acts as misdeed (Bdnews24.com, 2019). Along with bearing firearms and sharp objects the local community alleged of seeing other domestic weapons which are also available to Rohingyas. Local people, experts and law enforcers expressed their grave concern over the increasing number of weapons to Rohingyas (UCA News, 2017).

\subsection{Rape and Sexual Harassment}

More than 31 cases have been filed about rape and attempted rape against Rohingyas mostly inside camp and some are outside camp as Table 1 suggested. According to Post Traumatic Stress Order Theory, the human sense, morality and norms naturally do not work to people while he/she has horrendous experience or is going through a disastrous condition of life, inhuman treatment, having uncertainty of basic rights, minimal condition human rights and no conformity of getting justice (National Institute of Mental Health, 2019). So the growth of crime activities like rape, and attempt rape has been increased. Allegations mainly came from the Rohingyas against their own nationals and sometimes it has come from tourists and locals of being sexually harassed. Rohingya youth allegedly tease girls and women through verbal and attitudinal indication. Sometimes they whistle and utter awkward something before of girls. So the fear of sexual harassment is getting escalated.

\subsection{Murdering and Committing Violence}

Individual, familial and tribal strife are being intensified day by day, which inflicts huge amount of violence and results casualties inside the camp. The conflicts are mainly for establishing dominance and leadership on several issues including repatriation, rehabilitation, tenting and the distribution of foreign aid. At least 22 people were reportedly killed including one of tribal leaders inside the camp (Molla, 2019). Therefore recently the tension between local and Rohingys have been also escalated that resulted in a large scale violence. Usurpation of the local people's land, allegation and counter allegation of crimes as well as expressing hatred are the main reason of conflict. Local people have always blamed Rohingyas for inciting violence while the Rohingyas denied of carrying any liability.

\subsection{Narcotics}

Drug trafficking is one of the grave allegation against Rohingyas in Coxs' bazar. Bangladesh has recently opened its border for allowing Rohingyas free access in the humanitarian viewpoint. But the opportunists grab this as the chance to import Yaba, Heroin, Fencidil, Marijuana and others narcotics. According to Reuters, Bangladesh has recently become the big market of Drug (Das, 2017). According to Government, A record number of methamphetamine pills around 53 million were retrieved by the law enforcement officials in 2018 (Gulf News, 2019). Police officials of Cox's Bazar were interviewed, while one of them said "the border region has been vulnerable for being used as the hub of drags trafficking. Due to government's Anti-narcotics operations in mid of 2018, it had been limited, but for few days. Now it turns into its own wave again" ${ }^{1}$. However the Anti-Narcotics operation was accused of extrajudicial killing by Amnesty International and other human rights organizations (Gupta \& Pokharel, 2018). Moreover the massive and unregulated influx of Rohingyas make it difficult for the local administration to end this drug trafficking. Rohigya young people are mostly unemployed. So it has been very easy for the local or global drug smugglers to abuse them into drug trafficking.

\subsection{Human Trafficking}

Rohingyas particularly child and women are at the eyes of human traffickers. According to Police officials of Cox's Bazar several groups are active in abduction of women and children and trafficking them into abroad particularly to Middle East countries as slave and sex slave (Al-Jazeera, 2019). Therefore sometimes the abductor also claims money instead of releasing kidnapped individuals. However, some recent incidents of kidnapping have added new tensions among the locals and travelers particularly to woman and children. Tourists nowadays have alleged not to have enough security measures on spots. The accusation of abduction rate has also been increasing alarmingly (The Independent, 2019). Experts urge the government to take initiatives immediately unless the situation goes out of control.

\subsection{Robbery and Hijacking}

According to police officials of Cox's Bazar, at least 9 cases have been filed about robbery and hijacking against Rohingyas till July 2019 since the 2017 while the recent influx has newly begun (Khan, 2019). However, the robbery and hijacking are being increased rampantly due to lack of sufficient police patrolling, proper monitoring over the Rohingyas movement and disproportionate grow of Rohingyas across the town than the number of law enforcers. Police recently identified some spots are considered danger zone of robbery and 
hijacking. Robbery and hijacking many times turn into causalities. Many people alleged to get stabbed while they came under attack by the hijackers or robbers. Thus, growing number of incidents have concerned locale as well as tourists to move freely or to stay outside at night.

\subsection{Insurgency Threat}

In recent days it has seen a number of national and international terrorist outfits who became active in Cox's Bazar. Arakan Rohingya Salvation Army (ARSA) is one of the Rakhain based leading terrorist organization. ARSA has claimed responsibility of leading several attacks on military post and government installation of Myanmar in Rakhain. The recent ongoing military offensive has begun in response of those attacks. In recently, a large number of ARSA members have been operative in Bangladesh as many news media reported (Alam, 2018). They are allegedly plotting terrorist attack on Myanmar by using Bangladesh land. The number of ARSA operatives inside the Rohingya camp as active is nearly 3500 as estimated (Conrad, Czimmek, \& Islam, 2019). Pakistani Taliban named 'Tehrik-E-Taliban Pakistan (TTP)' has also declared to activate their base in Bangladesh. A leader of TTP is seen recently urging the Rakhain Muslim to take arms against Myanmar military. It also pledged to give all sort of assistance in terms of militancy training, arms and intelligence (ABC News, 2015). In recent days Al-Qaeda also have conveyed Bangladeshi Muslim to get together and wage war against Myanmar army (Dhaka Tribune, 2017). As well as different fundamentalist groups and opportunist networks are also allegedly trying to abuse Rohingyas for pursuing their diverse political objectives.

\subsection{Crime Acts on Tourist Spots}

Many Rohingyas in tourist spots are mostly involved with stealing and sweeping the accessories, luggage and precious goods of tourist while they find them unconscious. It is also happened while travelers are down to sea for swimming. It creates an environment of fear while the travelers need to be concerned about their accessories. Such incidents of losing accessories and bags turn the tour into very undesirable and horrible of someone's life.

Cox's Bazar hosts usually the tourists from across the world varied of social and cultural backgrounds. So, attire, dialects, appearances and behaviors have been varied in person to person. However, Rohingya youngsters many times react very harshly with laugh at, ridicule and tease particularly the female travelers on beach.

Teasing, jeering, whistling and odd indications to girls in verbal and attitudinal forms have recently become common in cox's bazaar. In most case the Rohingyas particularly the youngsters are found involved with such crime which is considered as sexual harassment. Many times, the harassment reached to danger level and ended up with rape and gang rape.

Many Rohingyas including their child are seen begging for living hood. The begging strictly is prohibited since it creates an awkward situation at tourist spots. But by eluding the eyes of law enforcers many beggars are appeared at spots. Many times, they seek financial help by catching up hands and legs, stretching cloths of tourists that seemed very awkward and embarrassing.

\section{Environmental Cost}

Cox's Bazar has witnessed a massive range of environmental damages including digging hills, rampant deforestation due to indiscriminate settlement of Rohingyas which are breeding worst consequences over the environments. Thus, environmental destruction has badly impacted and reasoned for the decline of scenic beauty, ecological imbalance and the spoiling of tourism friendly atmosphere in Cox's Bazar. The number of tourists subsequently has fallen. The effects of such environmental destruction have also impacted the lifestyle, living conditions and livelihood of the local people. The dream city, Cox's Bazar has been gradually turning into unlivable due to adverse environmental condition, mass congestion everywhere and excessive pollution. Nowadays the life of biodiversity is also at risk due to repercussion of climate change.

Table-2. Impact on forestry in Teknaf and Ukhiya upazilas.

\begin{tabular}{|c|c|c|c|c|}
\hline Upazila & Land acquired & Lost forest assets & $\begin{array}{ll}\text { Created } & \text { forest } \\
\text { asset lost } & \\
\end{array}$ & $\begin{array}{l}\text { Daily firewood nee } \\
\text { (in camps) }\end{array}$ \\
\hline \multirow[t]{2}{*}{ Teknaf } & 125 acres & Tk. 50 core & Tk. 3 crore & 50 tons \\
\hline & & US $\$ 6.0$ million & US $\$ 0.36$ million & \\
\hline \multirow[t]{2}{*}{ Ukhiya } & 5000 acres & TK. 500 crore & Tk. 235 crore & 650 tons \\
\hline & & US $\$ 60.2$ million & US $\$ 28.3$ million & \\
\hline
\end{tabular}

Source: Prepared by UNDP based on Forest Department, Cox's Bazar Sadar (UNDP Bangladesh (2018); (Islam (2020).

\subsection{Deforestation}

According to Cox's Bazar forest office, Rohingyas have already cleared nearly 6125 acres forest land in Ukhiya and Teknaf where they set up their inhabitants. Massive deforestation took place in order to meet growing need of firewood, furniture in addition to other daily needs. The Cox's Bazar environment has been facing immense threat from the Rohingyas, as the deforestation continues increasing. In the estimation of the Forest office, the cost of the damage is around 788 crore TK. 


\subsection{Demolition of Hills}

According to UNDP report of 2018 , the half of hill forest has been already cleared in Ukhiya and Teknaf area. Rohingyas indiscriminately cut down the trees for housing, collecting fire woods and in order to make furniture as well (UNDP, 2018). Rohingyas also continue digging hills in order to facilitate the walkway and make the place convenient for their living. However, it results in large scale landslide and soil erosion. The deforestation has also created a huge backlash on the whole environment including impacts on biodiversity life and ecological balance. This results in natural calamities and climate change as well (Huq, 2019).

\subsection{Ecosystem and Biodiversity}

The biodiversity of Cox's Bazar area is in threat due to large scale of deforestation. According to UNDP report of 2018 , at least 28 factors are created for Rohingyas, responsible for damaging the biodiversity in camp area. Due to shortening of the forest area the wild elephant has entered into local area and inflicted a large number of casualties including at least 13 deaths and many more injures. However, a large number of unknown species are also at risk of being vanished due to wide range of deforestation (Alam, 2018).

\subsection{Air and Water Pollution}

A large number of tube wells have been set up in order to meet the demand of water inside the Rohingya camps. The aquifer of water has subsequently downed. It impacts upon the whole surface like diminishing the moisture of soil. The whole area has rapidly turned into barren. A very few Trees actually can grow up in that area due to lack of moisture in soil. Many people including NGO workers, Visitors, Volunteers, Government officials, national and International personalities and law enforcement teams travel into Rohingya camps almost every day. The smoke from excessive traffic, firewood, sometimes from burning forest along with excessive particles and stenches turns the whole area into uninhabitable. So many air borne diseases including Cancer, Influenza, Chickenpox, Tuberculosis TB, Diphtheria, Bronchitis and etc. have been widespread in those area in accordance of WHO in 2019 (WHO 2019).

\subsection{Mass inhabitants of Rohingyas}

Many Rohingyas has moved away from campsite and set up tents on beaches and parks. Some also make tents near the market place and beside road. Some others also settled on the verge of hill that makes bad impact on local environment posing a threat of landslide. However, such large gatherings of Rohingyas diminish the natural beauty in one side and on the other side have shrunk beach and tourist zone.

\subsection{Waste Management}

More than 1.1 million Rohingyas settled in Ukhiya and Teknaf, two sub districts of Cox's Bazar have been producing a huge number of disposals and solid wastes (UNDP, 2018). The waste management has nearly been collapsed due to small capability of local authority compared to large quantity of disposals (Hayes, 2019). This actually makes negative impacts on local community health. Some limitations of that area have also pushed the problem into more trajectory including Jeopardized and congested settlements, poor connectivity, unregulated dumping, inadequate space for communal pit, low level of sanitation knowledge and adjustment, poor infrastructure and technology as well as excessive rainfall (Asad, Khan, \& Zion, 2019). Several disease including diphtheria, diarrhea, and dengue have been already spread out among Rohingyas and community people as well.

\subsection{Epidemic Virus and Communicable Diseases}

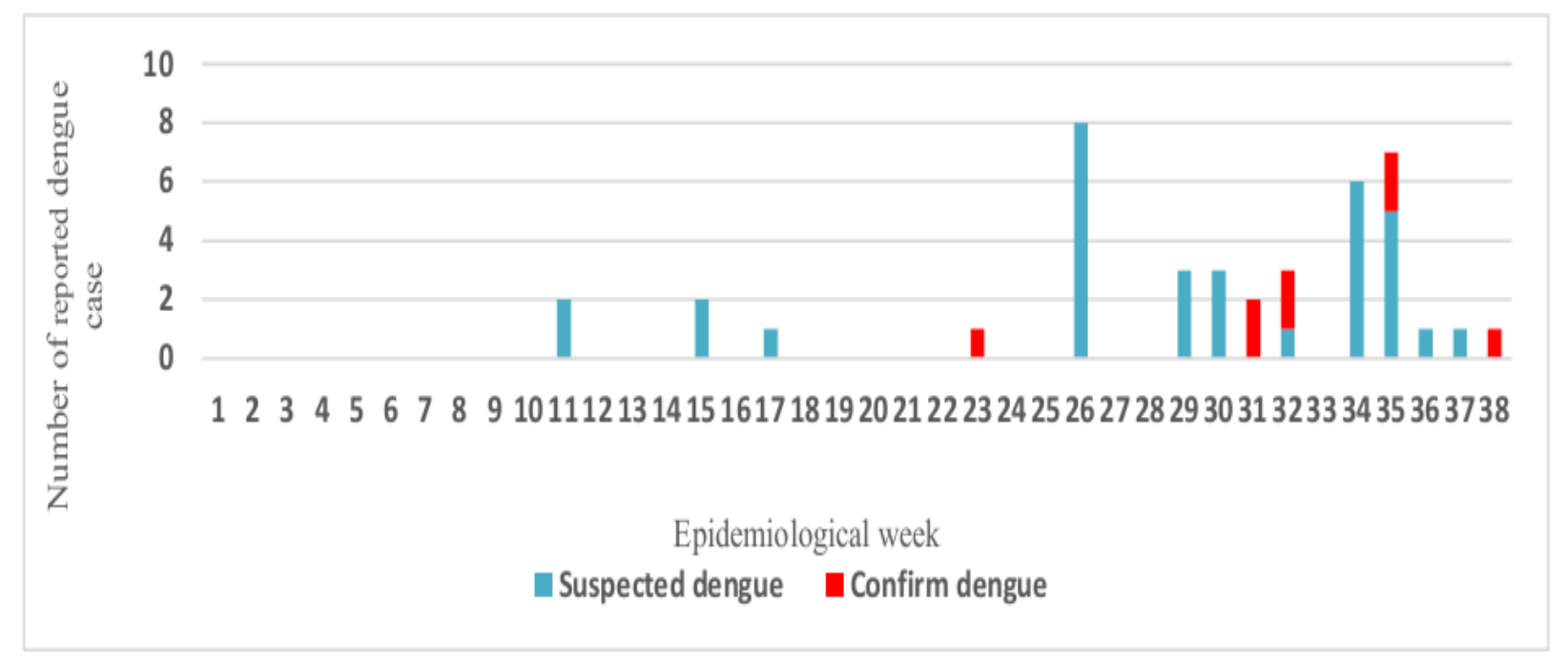

Figure-8. Number of reported dengue cases from camps for the week of 01 to 39 week in 2009, Cox's Bazar. Source: WHO. (2019).

After having completed a research on Rohingya camps for 37 weeks World Health Organization WHO reported to have at least 8 people confirmed of dengue patient and 33 people as suspects. 


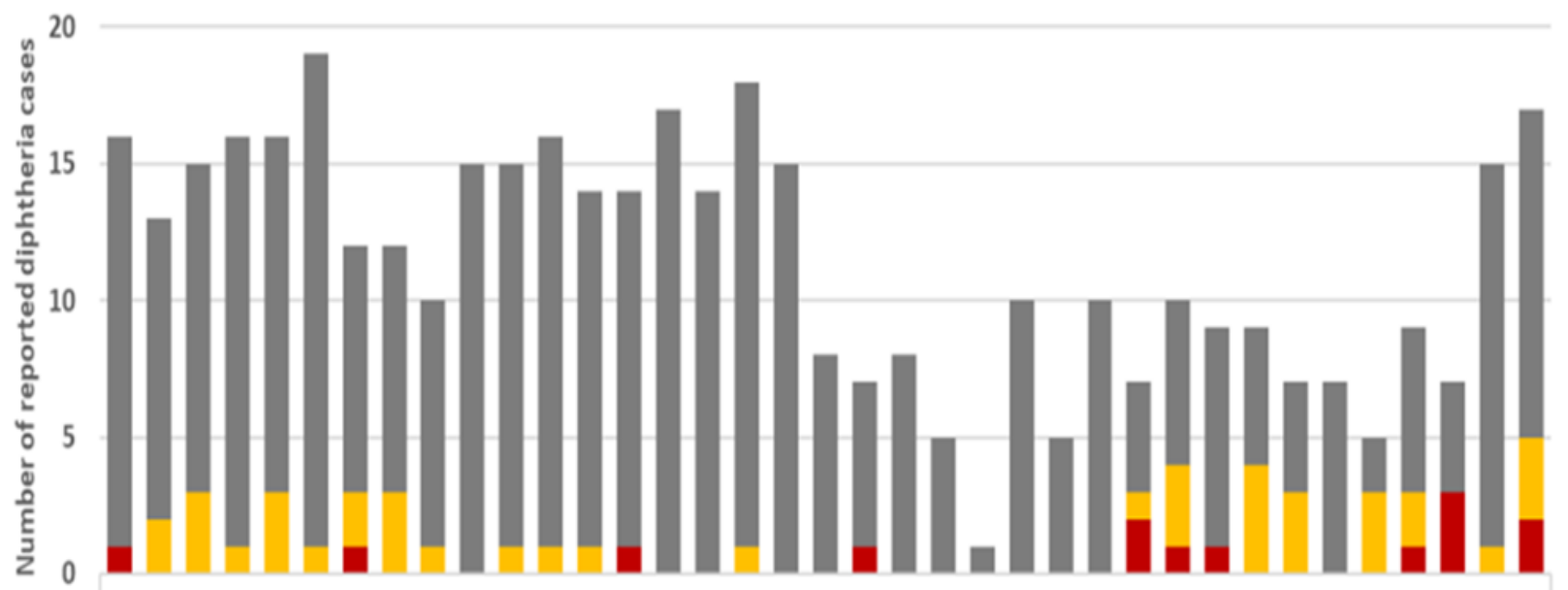

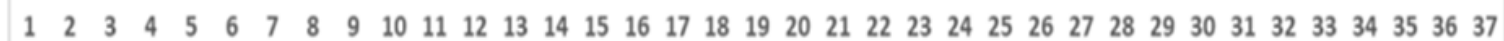
2019

Reporting Period

\section{- Confirmed Probable - Suspected}

Figure -9. Number of reported diphtheria cases from camps for the week of 01 to 39 week in 2009, Cox's Bazar. Source: WHO (2019)

WHO (2019) demonstrates that the number of patients who has been confirmed of Diphtheria disease is 306. Therefore 2749 people are in danger level and 5714 people are also identified as suspected of this disease. Therefore, the figure illustrates a clear rise of the disease in last two weeks among 37 weeks of observation.

However, at the same time it has found 6189 diarrheal cases among which 4615 cases were identified with Acute Watery Diarrhea (AWD), 385 cases were bloody diarrhea and 1189 cases were reported to suffer another diarrhea (WHO, 2019).

\section{Impacts on Tourism}

\subsection{Security Warnings from Different Embassy}

Large exodus of Rohingyas into Bangladesh and unchecked mobilization of them across the country particularly towards tourist spots has grown wide range of insecurity and fear among tourists who has come mainly from across the world including inside and outside of the country. Bangladesh based different embassy and high commissions including US Embassy Dhaka (2019) and UK (2019) warned their citizen to stay cautious during travel. The increasing number of crime activities in Cox's Bazar area was mainly responsible for making these warnings.

\subsection{Declining Trend of Tourism Contribution to Bangladesh National GDP}

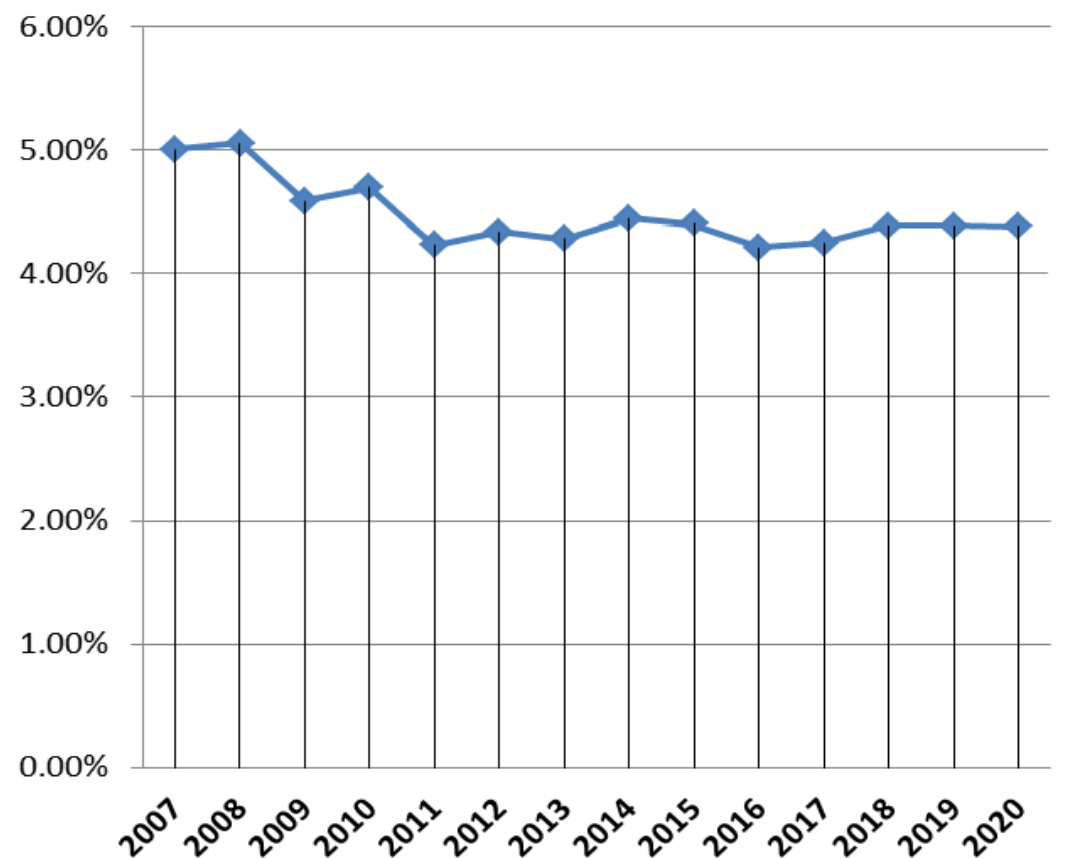

$\neg$ Changing flow of GDP contribution

Figure-10. Tourism contribution to Bangladesh national GDP.

Source: World Travel and Tourism Council Data (2019); World Data Atlas (2019). 


\begin{tabular}{c|c|c}
\multicolumn{2}{c}{ Table-3. Tourism contribution to Bangladesh national GDP. } \\
\hline Year & Value (\%) & Change (\%) \\
\hline 2020 & 4.38 & 6.83 \\
\hline 2019 & 4.39 & 7.56 \\
\hline 2018 & 4.39 & 11.38 \\
\hline 2017 & 4.25 & 8.23 \\
\hline 2016 & 4.21 & 2.35 \\
\hline 2015 & 4.41 & 5.52 \\
\hline 2014 & 4.45 & 10.28 \\
\hline 2013 & 4.28 & 4.45 \\
\hline 2012 & 4.34 & 9.42 \\
\hline 2011 & 4.23 & -4.22 \\
\hline 2010 & 4.70 & 8.04 \\
\hline 2009 & 4.59 & -4.69 \\
\hline 2008 & 5.06 & 7.18 \\
\hline 2007 & 5.01 & 7.03 \\
\hline Source: World Travel and Tourism Council Data (2019); World Data Atlas (2019).
\end{tabular}

Figure 10 and Table 3 illustrates the declining rate of tourism revenue since 2008 when it was at the highest level around $5.1 \%$ of total GDP. The fall of tourism contribution to GDP has begun latter although having some ups and downs. In 2015 the tourism contribution to GDP was nearly $4.4 \%$ that had overthrown sharply to $4.2 \%$ in 2017 . In 2018 the revenue had been slightly increased reaching to $4.4 \%$. Therefore in 2019, the growth rate has slightly decreased and that has continued until 2020. However according to World Travel and Tourism council report 2018, Bangladesh stood at $161 \mathrm{in}$ terms of tourism contribution to National GDP across the world. according to world economic forum report 2019, Bangladesh stood $120^{\text {th }}$ in terms of global Travel and Tourism Competitiveness Index 2019 (TTCI) while it has scored 3.1 (Calderwood \& Soshkin, 2019).

\section{Conducive Factors for Rohingyas to Commit Crime}

Rohingyas are seen creating threat elements in Cox's Bazar security situation due to having some conducive elements on the ground. The first reason is identification problem. The behavior, appearance, lingual feature and others identification features are mostly similar with local community. So, it is difficult for law enforcers to detect Rohingyas while they get merged with local community. The fake documents are also creating the identification more problematic. In recent time, Rohingyas are found bearing Bangladeshi national ID card and passport to travel abroad particularly to Middle Eastern countries. However, many times they get involved with crime and were detained. But unfortunately, the defamation has been carried out by Bangladesh due to their carrying Bangladeshi passport and identity. It has been spreading discredit of Bangladeshi across the world. Rohingyas mainly collected the passport and ID card which were retrieved from them recently through forgery. Thus, it also makes threat for the national security.

The second most concerning aspect is hired crime. Bangladesh due to having political tensions, disunity and criminalized structure increases the risk from Rohingyas. A large number of unemployed Rohingya youths are particularly identified as mostly vulnerable to be abused in pursuing political aims. The global terror outfits have recently declared to extend their activities by equipping Rohingya youths. It is very possible to be abused by such terror network as the ground for leading militancy across the region.

Social exclusion is the third essential factors that provokes the situation more crime prone. The uncertainty of the living space, unaffordability of basic needs including food, health, security, disadvantaged housing conditions and low life expectancy are deepening the social exclusion among Rohingyas (Abdullah, Basharat, \& Kamal, 2012). The social exclusion negates the values of humanity, social interaction, bondages and communication. Rohingyas in somewhat can be said having less sensitivity to the human feelings and emotions that turn them into brutality and disgrace activities (Waddington, 2000). So, the tendency of doing crime has been increased and the fear of punishment simultaneously has been decreased (UK Essays, 2018). Lack of proper parenting is also accounted for inciting the Rohingya child to crime. Parenting is a crucial step for a child to build its personality and social behavior. In according to Kevin N. Wright and Karen E. Wright, the child is highly at vulnerable of being involved at crime in absence of their father. Paternal direction, inspiration, and encouragement to child have been considered the basic tenets of shaping the child personality (Dina, Christopher, Travis, \& Satenik, 2004). The father in most case has been the iconic figure to their child. The maternal affection offers child the virtues of love, conscience, compassion and fairness. The child has risk of being arrogant and brutal in absence of their mother (Popenoe, 1996). However, a large number of Rohingya children has been rearing up at orphanage or in camp particularly who lost their parents or any of them. In many times the Rohigya parents are also even unable to do well parenting of their child due to uncertainty of living space and condition, inadequate knowledge, insecurity of basic needs and lack of consistency in lifestyle.

\section{Recommendation}

After having a rigorous analysis and scrutiny of Cox's Bazar situation, the study has reached some probable recommendations or measures which are thought to improve the situation.

The first measure is imposing strict supervision on Rohingya people inside and outside of the refugee camp. Government though has deployed Army in order to halt their exit from camp. However, deployment of army is considered as a great development but not enough. Another law enforcement agencies and government intelligence should have great involvement. In such effort the inclusion of local expert and community people in building security management is immensely needed. In most case the law enforcement team can't distinguish the Rohingyas from local community for having common appearance and lingual 
feature. So the involvement of local people can facilitate the process in an effective way. Overall a national task force is also needed to make better coordination of all efforts by the government and Non-government organizations with a view to preventing all forms of security threat from Rohingyas.

The second measure should be organizing seminar, symposium \& interactive public session in order to grow the consciousness and knowledge among general people regarding the problems created by Rohingyas and its impacts. The people should also be kept in touch for having better coordination in implementing the preventive measures taken by the law enforcers, NGOs and local administration.

The third step should be taken to prevent the deforestation of hill forest and forest area. It also requires replanting a large number of tress in forest area which has been already cleared by the Rohingyas. Government should take concrete measure to save the environment and forest from being demolished further. The involvement of local people should be encouraged in order to resist massive deforestation through organizing social movement.

The last measure is strengthening the tourist police with increasing manpower, advanced equipment and training facilities. It is alleged by the tourists and businessman of not having enough security personnel at the ground. The authority also admitted the problem as there is shortage of manpower. At the same time, the training facility for the tourist police is also poor. So, the increase of tourist police with offering proper training is imperative.

\section{Conclusion}

Tourism, the most potential economic sector of Bangladesh, which contributed $4.4 \%$ value to national GDP in 2019 has now hampered by the unchecked migration of Rohingya refugees into Cox's Bazar. Nationals and foreigners more than hundred thousand travelers come usually into Cox's bazaar every year. But recently the number of tourists in Cox's bazaar has been reduced disproportionately. This has badly impacted the tourism and its associated more than one million people's life. This article mainly explored the problematic scenario of Cox's bazaar which is mainly attributed due to unrestraint exodus of Rohingya refugees. The article clearly demonstrated different types of crime like murdering, smuggling, robbery, hijacking, rape, attempted rape and narcotics which have been growing rapidly in Cox's Bazar area. Rohingyas currently are seen infiltrating into different tourist spots and committing some spot crimes like snatching luggage and accessories, harassing women, creating chaos and treating tourist badly on beach and other spots as a regular basis. Environment is being also spoilt by wide range of deforestation and digging of hills. Rohignyas' makeshifts on beach and spots are attributed to spoiling the scenic beauty of that area. WHO has recently reported the outbreak of some communicable diseases like, diphtheria, dengue, diarrhea and AIDS in Rohingya camps and neighboring local area Insecurity, declining scenic beauty, outbreak of disease and unintended chaos are creating disinterest among tourists from domestic and abroad, push them to go to alternative tourist hubs including India, Nepal, Thailand and Singapore. Government officials, businessmen, and nearly 1 million people who are directly or indirectly associated to tourism for their livelihood expressed their disappointment and distress. It is a precaution from the expert community to stop such actions by immediate measure. A large effort is also needed to rebuild the confidence of tourists regarding security conditions of Cox's Bazar. Otherwise it predicts to face fresh overthrow in tourism revenue of Cox's Bazar.

\section{References}

ABC News. (2015). Pakistani Taliban urges Muslims in Myanmar to 'take up the sword' against country's leaders. Retrieved from: https://www.abc.net.au/news/2015-06-09/pakistani-taliban-call-for-jihad-in-myanmar/6530878.

Abdullah, M. A., Basharat, Z., \& Kamal, B. (2012). Is social exclusion pushing the Pakistani Hijras (Transgenders) towards commercial sex work? a qualitative study. BMC Int Health Hum Rights 12-32.

Al-Jazeera. (2019). Rohingya girls rescued from traffickers in Bangladesh. Retrieved from: https://www.aljazeera.com/news/2019/05/rohingya-girls-rescued-traffickers-bangladesh-190512101949513.html.

Al-Jazeera News. (2018). Who are the Rohingya? Following Myanmar's fleeing Rohingyas show the late 1970 nearly one million Roingyas Muslim have fled Myanmar due to widespread persecution. Retrieved from https://www.aljazeera.com/indepth/features/2017/08/rohingya-muslims-170831065142812.html. [Accessible 02/02/2020].

Alam, M. (2018). How the Rohingya crisis is affecting Bangladesh — and why it matters. The Washington Post.

Albert, E., \& Maizland, L. (2020). The rohingya crisis. New York: Council on Foreign Relations.

Arraiza, J. M., \& Vonk, O. (2017). Report on citizenship law. Myanmar: European University Institute.

Asad, A., Khan, A. M., \& Zion, B. (2019). A large number of people living in squalid conditions and in need of proper solid waste management Dhaka Tribune. Retrieved from https://www.dhakatribune.com/climate-change/2019/09/15/a-large-number-ofpeople-living-in-squalid-conditions-and-in-need-of-proper-solid-waste-management.

Bdnews24.com. (2019). Bangladesh suspends NGO projects for 'making' sharp weapons for Rohingya refugees. Dhaka. Retrieved from: https://bdnews24.com/bangladesh/2019/08/29/bangladesh-suspends-ngo-projects-for-making-sharp-weapons-for-rohingyarefugees.

Benar News. (2019). Map: Rohiynga camps of Bangladesh, Benar news. Retrieved from: https://www.benarnews.org/english/news/infocus/exodus/Story24.html. [Accessed 02/04/2019].

Bruce, C. N. (2017). Rohingya crisis in Myanmar Is 'Ethnic cleansing' U.N. Rights Chief says. New York: New York Times.

Calderwood, A. U., \& Soshkin, M. (2019). The travel \& tourism competitiveness Report 2019. World Economic Forum. 26-29. Retrieved from: http://www23.weforum.org/docs/WEF_TTCR_2019.pdf.

Conrad, N., Czimmek, S., \& Islam, A. (2019). Rohingya militants active in Bangladeshi refugee camps. Deutsche Welle. Retrieved from: https://p.dw.com/p/3PqzA.

Constantine, G. (2019). Between Burma and Bangladesh: Rohingya, a Stateless People. Pulitzer Center. Retrieved from: https://pulitzercenter.org/reporting/between-burma-and-bangladesh-rohingya-stateless-people.

Crosby, F. (1976). A model of egoistical relative deprivation. Psychological Review, 83(2), 85.Available at: https://doi.org/10.1037/0033295x.83.2.85.

Das, K. N. (2017). Stateless Rohingya refugees sucked into booming Bangladesh drug trade. London: Reuters.

Davis, J. (1959). A formal interpretation of the theory of relative deprivation. Sociometry, 22(4), 280-296.Available at: 10.2307/2786046.

Dewan, A. (2017). Who are the Rohingya and why are they fleeing? : Cable News Network.

Dhaka Tribune. (2017). Al-Qaeda calls on Bangladeshi Muslims to wage jihad against Myanmar army. Retrieved from: www.dhakatribune.com/world/south-asia/2017/12/24/al-qaeda-calls-bangladeshi-muslims-wage-jihad-myanmar-army/.

Dina, P., Christopher, S., Travis, P., \& Satenik, M. (2004). Parental efficacy, self-control, and delinquency: A test of a general theory of crime on a nationally representative sample of youth. International Journal of Offender Therapy and Comparative Criminology, 48(3), 298312.Available at: https://doi.org/10.1177/0306624x03262513. 
Edroos, F. (2017). ARSA: Who are the Arakan Rohingya salvation army? Doha: Al Jazeera. Retrieved from: https://www.aljazeera.com/news/2017/09/myanmar-arakan-rohingya-salvation-army170912060700394.html170912060700394.html.

Elbogen, E. B., Johnson, S. C., Newton, V. M., Straits-Troster, K., Vasterling, J. J., Wagner, R., \& Beckham, J. C. (2012). Criminal justice involvement, trauma, and negative affect in Iraq and Afghanistan War Era veterans. J Consult Clin Psychol. NIH Public. P., 80(6), 1097-1 102.Available at: 10.1037/a0029967.

Gulf News. (2019). Bangladesh makes record drugs seizure amid crackdown, Gulf News cited this news story from AFP. Doha. Retrieved from: https://www.gulf-times.com/story/621757/Bangladesh-makes-record-drugs-seizure-amid-crackdo. [Accessed $02 / 02 / 2020]$.

Gupta, S., \& Pokharel, S. (2018). Bangladesh defends war on drugs as body count mounts. CNN World. Retrieved from: https://edition.cnn.com/2018/06/08/asia/bangladesh-drug-war-intl/index.html.

Gurr, T. (1970). Why men rebel (pp. 10). Princeton: Princeton University Press.

Hayes, M. (2019). Waste not, want not at Rohingya refugee camps. Hong Kong: Asia Times.

Human Rights Watch. (2019). World report 2019: Myanmar Events of 2018. New York. Retrieved from: https://www.hrw.org/worldreport/2019/country-chapters/burma.

Huq, S. (2019). Rohingya crisis: Environmental challenges that can't be ignored. The Daily Star. Retrieved from: https://www.thedailystar.net/opinion/politics-climate-change/news/environmental-challenges-cant-be-ignored-1701073.

Husain, I., \& Ovi, I. H. (2017). Rohingya influx may hurt Bangladesh economy. Dhaka Tribune. Retrieved from: https://www.dhakatribune.com/bangladesh/2017/09/28/rohingya-influx-may-hurt-bangladesh-economy/.

Illius, S. (2017). 500 Rohingya children and women missing from camps. The Independent. Retrieved from: http://www.theindependentbd.com/printversion/details/115383.

Islam, M. T. (2020). Environmental cost: Rohingya mass exodus into Bangladesh. Bangladesh Institute of Peace and Security Studies BIPSS, $\begin{array}{lll}\text { Dhaka. } & \text { Retrieved from: https://bipss.org.bd/environmental-cost-rohingya-mass-exodus-into- }\end{array}$ bangladesh/?fbclid=IwARoIBcY3EdsH7mwnKfv4wqJBzMIiCyYd35Pg3YnzJ1OAYkdx_8haD9tpZvs.

Khaliq, R. U. (2019). Who are Rohingya? Istanbul: Anadolu Agency.

Khan, M. J. (2019). Curbing Rohingya crimes: New police unit on cards. Dhaka: The Daily Star.

Khan, T. I. (2018). Implications of the Rohingya crisis for Bangladesh. Third Meeting of the Bangladesh Economists' Network. Dhaka: Center for Policy Dialogue.

Mahmud, T. (2018). How NGOs are driving Cox's Bazar's economy. Dhaka Tribune. Retrieved from: https://www.dhakatribune.com/bangladesh/nation/2018/08/27/how-ngos-are-driving-cox-s-bazar-s-economy.

Maslow, A. H. (1943). A theory of human motivation. Psychological Review, 50(4), 370-396.Available at: 10.1037/ho054346.

McLeod, S. A. (2019). Id, ego and superego. Simply Psychology. Retrieved from: https://www.simplypsychology.org/psyche.html.

McLeod, S. (2020). Maslow's hierarchy of needs. Simply Psychology. Retrieved from: https://www.simplypsychology.org/maslow.html.

Molla, M. A. M. (2019). Refugee Camps: Crime spikes while Rohingyas despair. The Daily Star. Retrieved from: https://www.thedailystar.net/rohingya-crisis/news/refugee-camps-crime-spikes-while-rohingyas-despair-1744768.

National Institute of Mental Health. (2019). Post-traumatic stress disorder. Retrieved from: https://www.nimh.nih.gov/health/topics/posttraumatic-stress-disorder-ptsd/index.shtml.

OHCHR. (2017). Human rights council opens special session on the situation of human rights of the Rohingya and other minorities in Rakhine State in Myanmar, United Nation Human Rights, 05 December Retrieved from: https://www.ohchr.org/EN/NewsEvents/Pages/DisplayNews.aspx? NewsID=22491\&LangID=E. [Accessed 01/05/2019].

Patwary, S. H. (2017). Rohingya influx to hit tourism in Cox’s Bazar. The Daily Star: Dhaka. Retrieved from: https://www.dailysun.com/post/258987/Rohingya-influx-to-hit-tourism-in-Cox\%E2\%80\%99s-Bazar.

Pennington, M. (2018). Bangladesh point finger at Myanmar for Rohingya 'genocide'. Fox News. Retrieved from: https://www.foxnews.com/world/bangladesh-point-finger-at-myanmar-for-rohingya-genocide.

Popenoe, D. (1996). Life without father: Compelling new evidence that fatherhood and marriage are indispensable for the good of children and society: Martin Kessler Books. Retrieved from: https://books.google.com.bd/books?id=xk8BgG-WO7gC.

Runciman, W. G. (1966). Relative deprivation and social justice. Berkely: University of California Press.

Sigmund, F. (1962). The Ego and the Id (pp. 9-29): W.W. Norton and Company.

The Independent. (2019). Criminal gangs taking control of Rohingya camps, report warns. Retrieved from: http://www.theindependentbd.com/post/197182.

The Local. (2017). German refugee climax. Retrieved from https://www.thelocal.de/20181221/study-shows-the-tenuous-link-betweenforeigners-refugees-and-criminality. [Accessed 01/07/2019].

UCA News. (2017). Rohingya refugee arrested in Bangladesh, activists concerned. Retrieved from: https://www.ucanews.com/news/rohingya-refugee-arrested-in-bangladesh-activists-concerned/79750.

UK, E. D. (2019). Foreign travel advice Bangladesh: Safety and security.

UK Essays. (2018). Social exclusion deprivation. Retrieved from: https://www.ukessays.com/essays/criminology/social-exclusiondeprivation.php?vref=1. [Accessed 7 April 2020].

UNDP. (2018). Environmental impacts of Rohingya influx: A multifaceted problem requires multifaceted responses: UNDP Bangladesh. 49. Retrieved from: https://www.bd.undp.org/content/bangladesh/en/home/presscenter/pressreleases/2018/2009/2018/Environmental_impacts_of Rohingya influx.html.

UNDP Bangladesh. (2018). Impacts of the Rohingya refugee influx on host communities (pp. 87). Dhaka: UNDP.

UNHCR, B. (2019). Rohingya refugee response - Bangladesh refugee population density. Dhaka. Retrieved from: https://data2.unhcr.org/en/documents/download/71428.

US Embassy Dhaka. (2019). Travel advisory. Retrieved from: https://bd.usembassy.gov/travel-advisory-u-s-embassy-dhaka-bangladesh/.

Waddington, P. A. J. (2000). Reviewed work 'Violent Racism: Victimization, policing and social context' by Benjamin Bowling. The British Journal of Criminology, 4O(3), 532-534.

Walter, I., \& Pettigrew, T. (1984). Relative deprivation theory: An overview and conceptional critique. British Journal of Social Psychology, 23(4), 301-310.Available at: https://doi.org/10.1111/j.2044-8309.1984.tb00645.x.

WHO, B. (2019). Emergency: Rohingya crisis (pp. 3). Dhaka: WHO.

WHO, B. (2019). Emergency: Rohingya crisis (pp. 2). Dhaka: WHO.

WHO. (2019). Emergency: Rohingya ccrisis. Dhaka: WHO Bangladesh.

World Data Atlas. (2019). What is Bangladesh contribution of travel and tourism to GDP (\% of GDP)? KNOEMA. Retrieved from: https://knoema.com/WTTC2019/world-travel-and-tourism-council-data. [Accessed 02/02/2020].

World Travel and Tourism Council Data. (2019). Bangladesh - total contribution to GDP. Retrieved from: https://www.wttc.org/datagateway. [Accessed 02/02/2020].

WTTC. (2019). Bangladesh - total contribution to GDP. World Travel and Tourism Council Data. Retrieved from: https://www.wttc.org/datagateway. [Accessed 02/02/2020]. 